\title{
Worldwide Hot Mix Asphalt Layer Application and Scrap Rubber and Bitumen Emulsion Studies on Railway Track-Bed
}

\author{
DIAN M SETIAWAN
}

\begin{abstract}
Researchers around the world have performed various studies on reinforcement of track-bed and mitigation of ballast deterioration. This paper objective is to conduct a literature review comprehensively to analyse and discuss the development of rubber, bitumen emulsion, and asphaltic layer usage on railway track-bed to study the proposed alternative of Indonesian unconventional rail track design concept. Various asphalt track-bed concept around the world have been reviewed (Germany, USA, Italia, Japanese, France, Spain, and Austria). Research on scrap rubber and bitumen emulsion in railway track-bed also examined in this paper. There are no researchers' uses these three methods together in their study. In fact, each design has its benefits and limitations, so if these three methods are combined, then they will complete each other and will produce better output. The author suggests developing a new track structural components design that combined asphalt layer, scrap rubber, and bitumen emulsion. This new design expected to have capabilities to serve highspeed railway and existing railway track corridors more cost-effectively compare to the conventional tracks in consequence of their potential to have greater structural stability, considerably lower maintenance works, and more service-life. It can serve the train journey with higher speed and higher axle load.
\end{abstract}

Keywords: Asphalt Layer, Bitumen Emulsion, Scrab Rubber, Unconventional Track

\section{INTRODUCTION}

Higher speed and axle load train demand worldwide and problems in conventional granular track system are the main reason for the unconventional railway track system development. Approximately in 1970, the first unconventional track systems have been developed and started to use. Nowadays, the increased railway speeds and axle loads are making the unconventional track design more fascinating (Michas, 2012; Setiawan, 2013).

Since there is a train traffic growth in Indonesian railway system, so the maintenance and renewal work becomes more complicated to carry out. The night-time possessions in The Netherlands railway systems often less than 5 hours and in Korean high-speed railway systems, the maximum time possession for maintenance and renewal is predicted at no more than 1.5 hours per night. Today, the principle of service life costing is brightly arising which is different from in the past, where the new railway projects were primarily calculated by financing budgets. This condition causes the conventional track concepts will lose attractiveness compared to the unconventional track systems (Esveld, 2003).

Nowadays, $100 \%$ of existing Indonesian railway network uses the ballasted (conventional) track systems. The tracks cover approximately 4,675 kilometres, 3,362 kilometres are located in Java Island, and 1,313 kilometres are in Sumatera Island. According to the Ministry of Transportation of Indonesia, around $30 \%$ of the railway lines were constructed with small radius curves $(300 \mathrm{~m})$.

There are many problems on ballasted (conventional) railway tracks that leading to the operational speed restriction and the need for increased track maintenance as an effort to prevent derailment accidents and to ensure passenger comfort. Generally, infrastructure (rail track) failures give the highest contribution to the train accidents.

Researchers around the world have performed various studies on reinforcement of track-bed and mitigation of ballast deterioration to propose multiple new technologies and solutions. A method that has been satisfactorily operated throughout the UK and now 
increasingly overseas to stabilise and strengthen ballasted railway tracks is the application of insitu polyurethane polymers, termed XiTRACK. This technique can be used to solve issues like ballast movement under high-speed train systems (Woodward et al., 2012). However, this technique has the main limitation which is related to low efficiency and also categorised as a special maintenance operation.

\section{RESEARCH METHOD}

Indonesia rich of scrap rubber, natural rubber and bitumen that can be used as elastic aggregates and mixed with ballast particles to help maintain track geometry and stability. These studies aim to perform a literature review comprehensively to analyses and discusses the development of rubber, bitumen emulsion, and asphaltic layer utilisation on railway track-bed, including its characteristics, advantages, disadvantages, and economic efficiency to study the proposed alternative of Indonesian non-conventional rail track design concept. This method will modify the track-bed structure and offer better resistance to permanent settlement and particle deterioration.

\section{RESULT AND DISCUSSION}

\section{Previous Studies on Ballasted Track Vs Slab Track}

Nowadays, the conventional track is the primary track type utilised in railways systems. According to the references (Profillidis, 2006; Esveld, 1997; Michas, 2012), the following are several motives that may lead to the conventional track system utilisation instead of an unconventional track: High elasticity due to ballast; Relatively low construction costs; Good travelling comfort at speeds up to $250-280$ $\mathrm{kph}$; Provide more accurate corrections and faster maintenance by using stone blowing and tamping machines; Better attenuation of the wheel-rail contact forces and noise by providing optimised rail pads and fastening; and Lower noise emission.

However, ballasted railway tracks experienced many problems. As shown in Figure 1a, in infrastructure such as small radius curves, high track forces can be produced resulting in higher ballast deformations and hence track misalignments (Setiawan, 2016). Also, rail track is often experienced ballast material deficiency in the transition section (due to soil subsidence and rainwater erosion (Figure 1b). The formation of the ballast pocket is also an important issue that is vulnerable to occur in the track structure, as described in Figure 1c (Yahya, 2012; Huang et al., 2014). The latter result in higher track forces and hence more settlement, leading to the operational speed restriction and the need for increased track maintenance to ensure comfort and safety. Current technologies for solving issues like ballast movement at small radius curves under high-speed and heavy trains system are limited (Woodward et al., 2012). Moreover, railway maintenance spends a considerable budget, complicated to set up and has many challenges related to coordination with rail traffic (Lidén, 2015; Tutumluer, 2011). Ballast conditions checking also requires specialised knowledge and tools, which are incorporated into the Track Quality Index measurement and can be done by various methods (Setiawan and Rosyidi, 2016; Berawi et al. 2010; Liu et al., 2015; Sadeghi and Askarinejad, 2012).

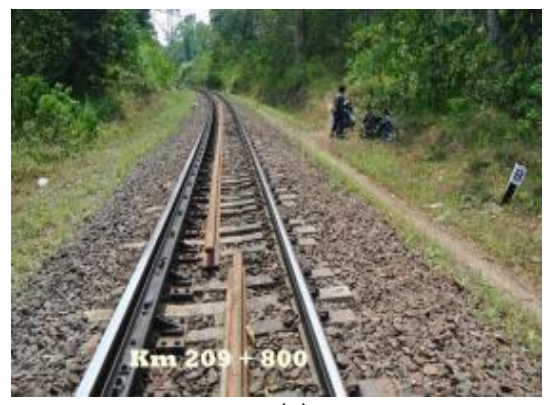

(a)

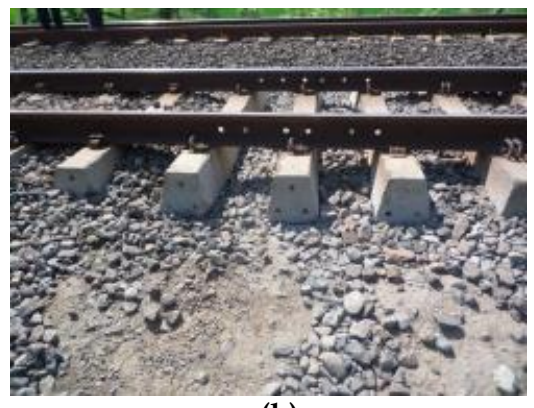

(b)

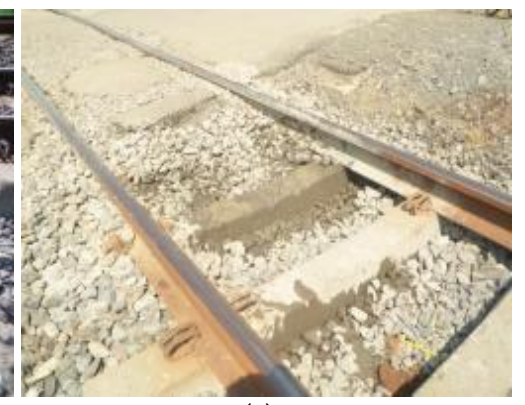

(c)

FIGURE 1. Ballasted Track Problems in Indonesia 
The study to compares the ballasted tracks concepts and slab track systems, as well as their advantages and disadvantages, had been performed by Michas (2012). His research: a). Investigates the different unconventional track systems that are being utilised today according to their structural behaviour, dimensions, country of origin, further developments, and construction method; b). Examines slab tracks structures and each layer properties; c). Introduces all the different types of slab track systems available around the world: d). Analysis the slab track systems by using ABAQUS models. At least 34 various slab track designs have been verified in different railway networks worldwide.

Every slab track possesses its features in each aspect. The ballast-less track has several benefits against to conventional tracks. It has higher stability, the almost non-existent maintenance requirement, longer life cycle (nearly 6 (six) decades) and lower track weight and height compared to the traditional type (Esveld, 2001; Esveld and Markine, 2003; Lichtberger, 2005; Profillidis, 2006; Setiawan, 2013). The ballast-less tracks have significantly better durability since it has higher stiffness and strength, so its deformation noticeably smaller than a conventional track. In contrast, traditional type of track is incapable of distributing the loads in large areas leading to the high stresses as well as large deformations around the areas of loading. Michas (2012) also stated that the need for slab track use is increasing, and these must be acknowledged to make future improvements.

However, the application of ballast-less track has specific attention related to the sub-ground, in level crossing, tunnel and bridge transition, for vibrations and noise emissions, and for signalling and electronic systems. Their weaknesses compared to the conventional tracks are primarily reviewed in their greater investment costs (Esveld, 2001; Lichtberger, 2005; Setiawan, 2013).

Setiawan (2013) research results supported the disadvantages of the slab track. His research objectives were to analyse and compare the conventional and unconventional railway track and to decide the most appropriate railway track be applied in railways track on soft ground in Indonesia. He found that the ballasted track is more suitable and more effective to be implemented on the soft ground in Indonesia compared to the slab track. It demands significantly lower material requirement than for unconventional track, offers more precise corrections and faster maintenance, and considerably lower investment cost. However, the conventional track only able to accommodate lower speeds in curves, flying of ballast materials due to the passing high-speed trains resulting in damaging of the rails and wheels, and limited availability of suitable ballast material. In another side, even though the slab track has a longer service life, greater structural track performance, lower maintenance works, and lower thickness requirement, however, the ballast-less track investment cost is greater than ballasted track ( 2 times higher). The slab track also needs homogenous subgrade with the minimum settlement, and not economically efficient in soft ground (Lichtberger, 2005; Profillidis, 2006).

\section{Hot Mix Asphalt In Railway Track-Bed}

This section discusses the various international practices of using the asphalt layer as opposed to the typically used granular layer and the bituminous sub-ballast layer as an underlayment below the ballast. Esveld (2001) stated that rail track structure with asphalt roadbed is categorised in the group of slab track structures though without a slab. Sleepers are placed on top of an asphalt roadbed layer. This roadbed constructed with conventional paving machines. It is possible to reach the level of accuracy of $+2 \mathrm{~mm}$ and cant-deficiencies of up to $180 \mathrm{~mm}$. Therefore, the asphalt offers a stable and level base for the sleepers. The space between the sleepers can be filled with ballast delivering extra stability and decreasing noise production. Asphalt does not require hardening and can be subjected to loading immediately after cooling, so high construction productivity can be reached.

According to Esveld (2001), promising experiences have been had with this kind of track in several countries. For example in Germany, several tests have been performed with stretches of sleepers directly applied on top of asphalt: 14,500 meters at Nantenbach (1993), 4,000 meters at Gotha-Eisenbach (1994), and 10,260 meters at Berlin-Hannover. 


\section{Asphalt Track-Bed Applications in German Railways}

The first asphalt slab track systems applied by Germany Railways was built almost 50 years ago. Until now, various options of track design both for the high-speed and conventional track have been produced, involving bituminous track designs (Rose, Texeira and Veit, 2011).

\section{ATD Systems}

The ATD-system consists of a concrete trackbed with an asphalt layer on top and directly applied sleepers on top of that (Darr \& Fiebig, 2006). The bituminous layer with $\pm 2 \mathrm{~mm}$ precision is constructed and is placed in 3 (three) to 4 (four) multi-layers (Figure 2a). The bituminous mixture could assure almost 60 -year service life (Esveld, 2001).

\section{Walter Systems}

The Walter slab track design utilises an asphaltic supportive layer (ASL) and the concrete sleeper which is tightly fixed together by a steel anchor rod that crossing the concrete sleeper as described in Figure 2b (Darr \& Fiebig, 2006 and Franz, 2001 in Michas, 2012).

\section{FFBS-ATS-SATO}

As shown in Figure 3, the FFBS-ATS-SATO system was constructed in Germany as a test section $(390 \mathrm{~m})$. A bituminous layer supports the track structure, and it is equipped with concrete sleepers. The sleeper with web plate compensates the transfer of lateral. In special grooves cut, the sleepers are poured into the asphalt supporting layer (Franz, 2001 in Michas 2012).

\section{GETRAC Slab Track System}

This ballast-less track design is founded in Germany in 2003 (Rose, Texeira and Ridgway, 2010 in Michas, 2012). It consists of a bituminous 2nd layer and pre-stressed concrete ties placed and anchored on this asphalt layer. GETRAC Slab Track System has two variants, named A1 and A3 type (Franz, 2001). The A1 type illustrated in Figure 4a which has a $2.6 \mathrm{~m}$ long concrete tie, and it is utilised in projects without any space restrictions. The A3 configuration displayed in Figure $4 \mathrm{~b}$ has a 2.4 $\mathrm{m}$ tie that is appropriate for constructions with space restrictions such as narrow tunnels (Rose,
Texeira and Ridgway, 2010 in Michas, 2012). The A3 ties designs have a greater bearing surface that decreases the contact pressure between the tie and the bituminous layer. This design allows for a $5 \mathrm{~cm}$ elimination of the thickness of asphalt supportive layer, making it more proper for improvement existing narrow tunnels by offering extra free space.

Due to its specific material properties, asphalt can be appropriate for slab track structures. The used asphalt mixtures do need alteration compared to the mixtures user for roads. In road construction, the essential properties regarding the surface (high friction-resistance and resistance to wear and tear) are subordinate to resistance to deformation and stability. In the case of unconventional track structures, deformation resistance and stability are the required most. Asphalt will adapt itself to stresses caused by loading and temperature changes which cause yielding. Therefore, asphalt can be applied as a continuous roadbed. Due to the internal damping properties of asphalt, noise and vibration are less compared to concrete. The material is moreover recyclable (Esveld, 2001; Lee et al., 2014).

The positive features of this asphalt track-bed are stated below (Rose, Texeira and Ridgway, 2010 in Michas, 2012):

- Beneficial geometrical structural capability to support accurate geometric alignment.

- Created to support the high speed and heavy goods trains.

- Quick and easy construction.

- Cost-effective and long service life with minimum preservation.

- Fast and simple-track restoration after the collisions of the train.

- High flexibility by decreasing the track total width or/and the cross-section thickness or/and the.

\section{Asphalt Track-Bed Applications in United States Railways}

In the early 1980s, some stakeholders of United States railroad and industry of the bituminous paving improved HMA applications and designs for utilising within the track structure to substitute the ballasted aggregate for providing higher stability and longer service life of the track structures. Asphalt track-beds applications have been principally limited to heavy hauling freight trains in the US, especially for track-bed 
rehabilitation, maintenance and instability problems solutions or capacity improvements of existing lines. It will be considered for application on the anticipated high-speed rail network in the United States. These track-bed solutions also involved asphalt layer installation during rehabilitation of various infrastructures, such as highway-railroad crossings, turnouts,

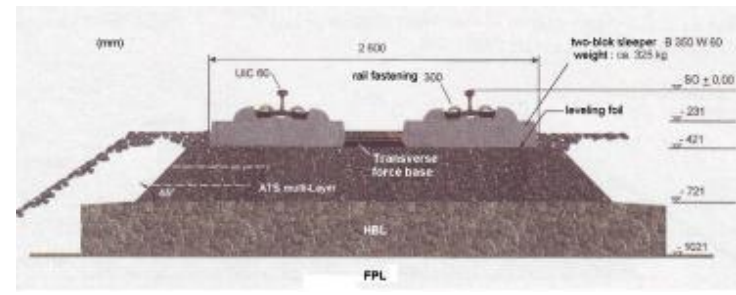

(a) deterioration detectors, bridge approaches, tunnel floors and transition, hump tracks, where the designs and support structures of ballasted track-bed had not performed suitably (Rose, 2013; Rose, 2014; Rose, Texeira and Veit, 2011). Figure $5 a$ and $5 b$ to Figure $6 a$ and $6 b$ illustrated the various design of asphalt layer in track structures

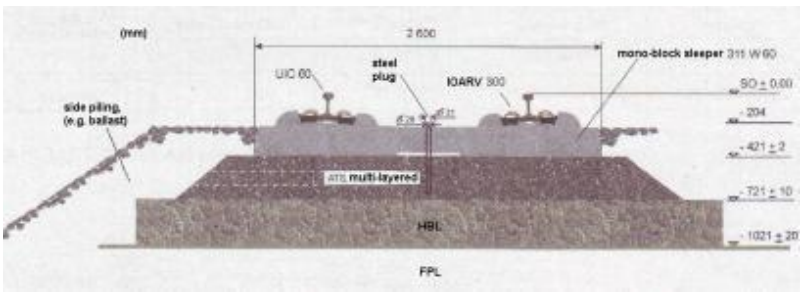

(b)

FiguRE 2. (a) ATD System Design; (b) Walter Slab Track System Construction (Darr \& Fiebig, 2006 in Michas, 2012)

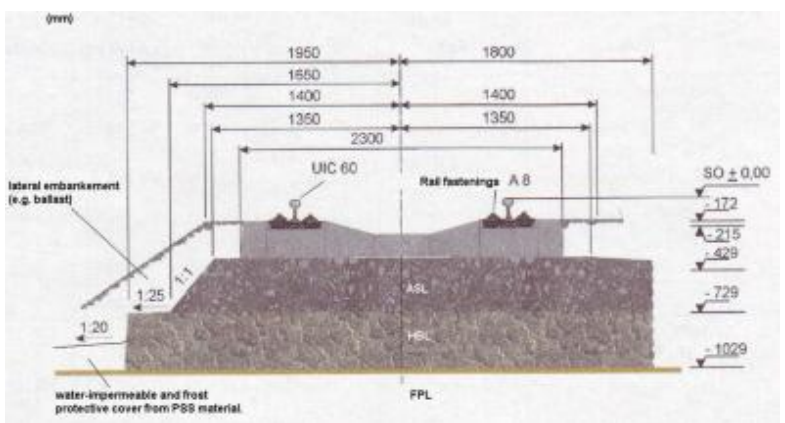

FIGURE 3. Slab Track Design of FFBS-ATS-SATO (Darr \& Fiebig, 2006 in Michas, 2012)

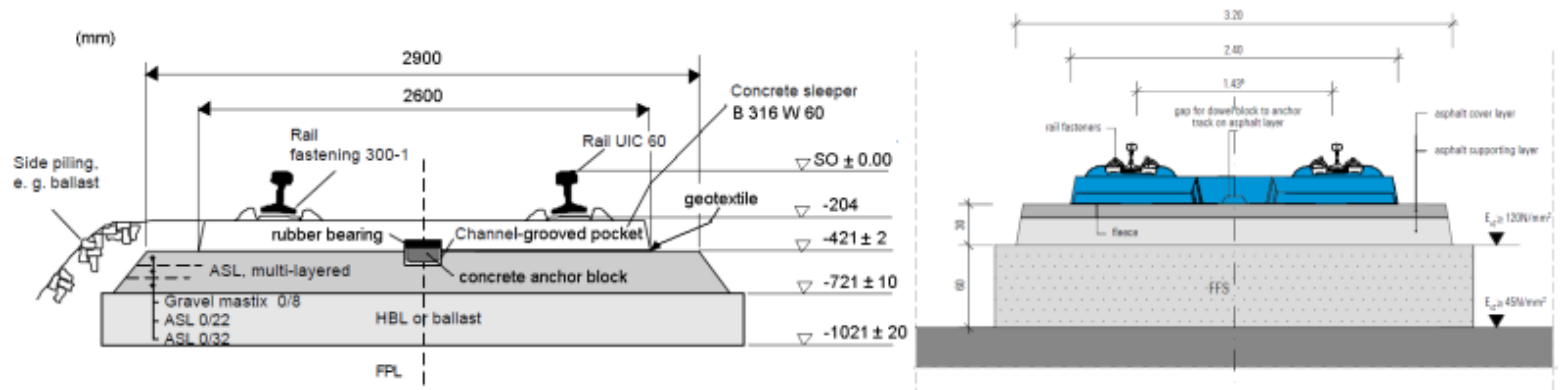

FIGURE 4. (a) Slab Track System of GETRAC A1 (Darr \& Fiebig, 2006, Lichtberger, 2005, and Franz, 2001 in Michas, 2012); (b) GETRAC A3 Slab Track Design (www.ssf-ing.de)
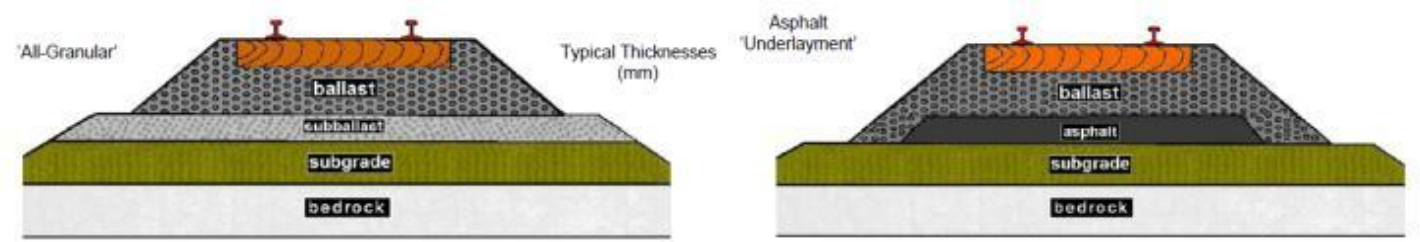

FIGURE 5. (a) Conventional Track-bed; (b) Asphalt Layer to Replace Subballast Layer (Rose and Souleyrette, 2014)
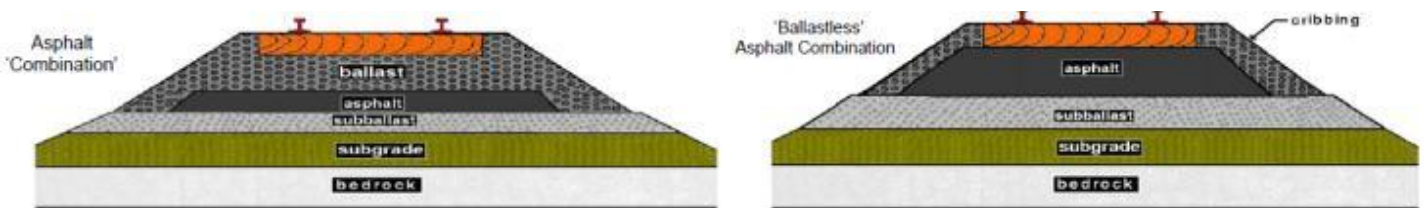

FIGURE 6. (a) Combination of Asphalt Layer and Subballast Layer; (b) Asphalt Layer to Replace Ballast Layer and with Subballast Layer (Rose and Souleyrette, 2014) 


\section{Asphalt Track-Bed Applications in Italian Railways}

The development and continued application of the Italian State Railways asphalt track-beds have been active since long time ago for their widespread high-speed rail network (Figure 7). According to Buonanno (2000), the asphalt track-bed performed the following utilities:

- Inhibit the infiltrating of rainwater to the layers underneath the embankment.

- Embankment failures and high-stress loads elimination.

- Freeze/melt prevention on the upper part of the embankment.

- Distribute static and dynamic stresses gradually.

- Reduce ballast deterioration.

The layer of asphalt sub-ballast offers some advantages. These benefits include (Teixeira and Lopez-Pita, 2005; Teixeira et al., 2006):

- Due to higher modulus and uniformity, it can improve structural and safety reliability.

- Since it can reduce subgrade fatigue, so it can decreased infrastructure service-life budget.

- It can enhance the consistency of bearing capacity of the track on the longitudinal section and strengthen ballast boundary.

- In consequence of drainage performance improvement, it can decrease ballast fouling.

- It can minimise noise since it can reduce vibration levels throughout the track.

- Compared to the conventional track design, it can produce lower structural thickness.

Asphalt Track-Bed Applications in Japanese Railways
For many years, the Japanese Railways have extensively constructed asphalt track-beds in the conventional track on both high-speed railways and regular railways. The critical asphalt track-beds utilisation objective has been to offer stable ballast support and to decrease track deterioration. This structure will minimise the subgrade load level to counteract deformation (Momoya and Sekine, 2007).

According to the performance-based design procedure, the track designs are ranked or classified into three different standards as follows:

- Asphalt track-bed or concrete track-bed for the ballast-less track (Function Level I)

- Asphalt track-bed for the conventional track (Function Level II).

- Aggregates track-bed for the conventional track (Function Level III).

The slab track that has either concrete or asphalt supportive layer with concrete sleeper directly fixed to the slab is classified into the Performance Rank I and it is considered as the track with the highest quality. The track settlement, fatigue damage, concrete reinforcement base breakage, contraction, thermal stresses, and cracking are several parameters that have to be checked for track sustainability.

For the Function Level I ballast-less track-bed, the typical dimensions as the followings:

- $2220 \mathrm{~mm}$ of the slab width.

- $190 \mathrm{~mm}$ of concrete slab thickness.

- $150 \mathrm{~mm}$ of asphalt-concrete base thickness.

- $150 \mathrm{~mm}$ of well-graded crushed stone layer thickness.

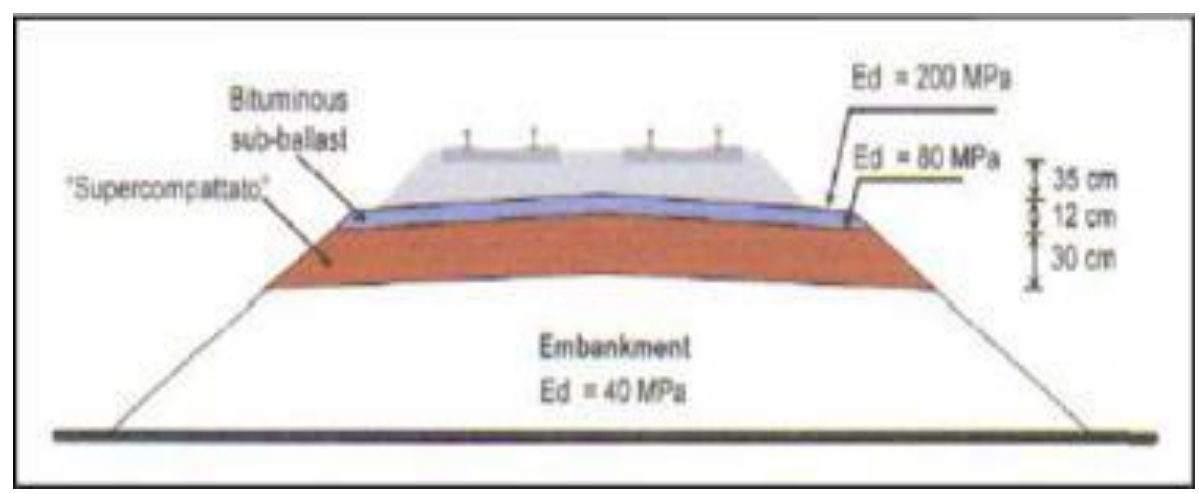

FIGURE 7. Cross-Sectional Profile of High-Speed Track Line in Italia

(Teixeira and Lopez-Pita, 2005) 


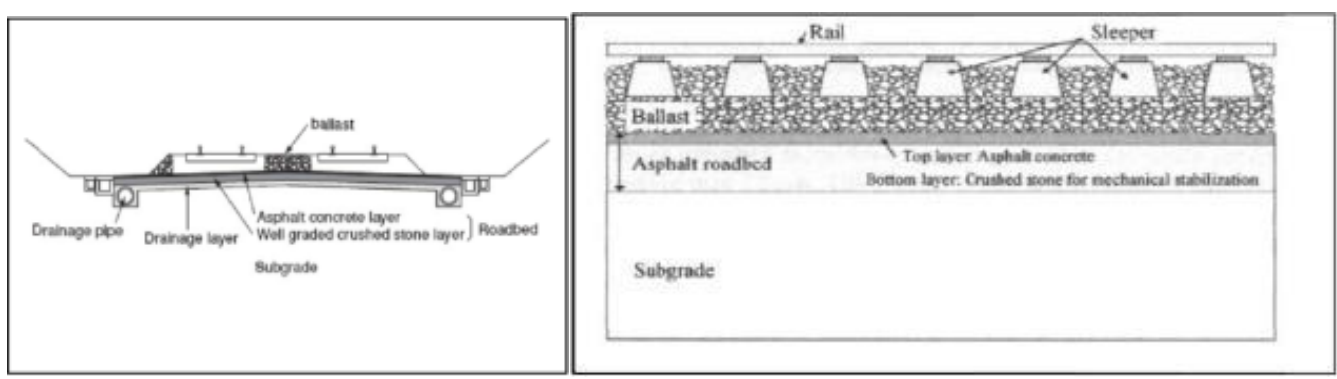

FIGURE 8. Cross-Sectional Profile of Performance Rank II (Momoya, 2007; Momoya and Sekine, 2007)

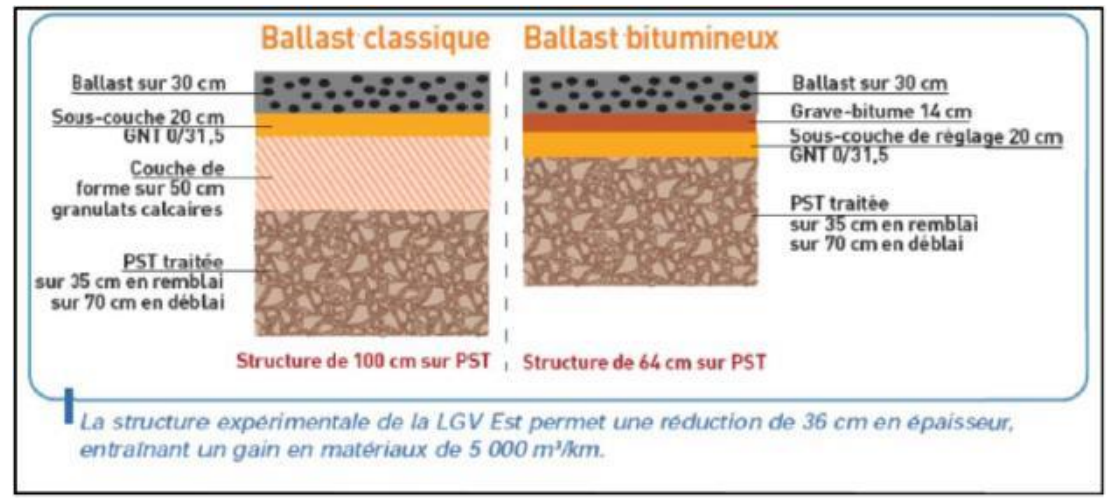

FIGURE 9. Cross-Sections Conventional and Asphalt Track-bed (Bitume Info, 2005)

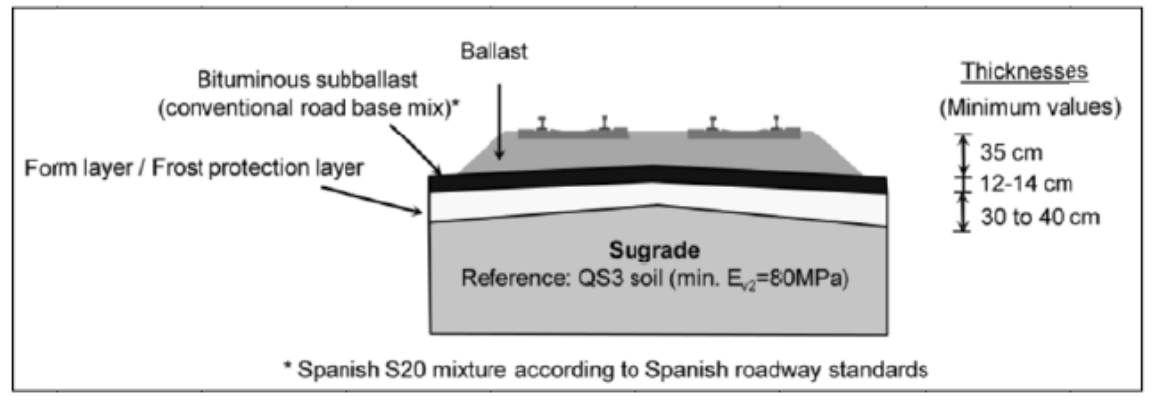

FIGURE 10. Asphalt Sub-Ballast Track Design for the Standards of Spanish High-Speed Lines (Teixeira et al., 2010)

A conventional track with asphalt layer thickness of $50 \mathrm{~mm}$ is classified into the Performance Rank II design. For over 30 years, this configuration has been utilised in Japan in consequence of the asphalt's capability to facilitate the drainage and distribute the loads. Track settlement and fatigue damage to the asphalt are the fundamental parameters. Figure 8 displays the dimensions of Performance Rank II:

- 250-300 $\mathrm{mm}$ of ballast thickness beneath sleeper.

- $50 \mathrm{~mm}$ of asphalt-concrete layer thickness.

- 150-600 mm of well-graded crushed stone layer thickness.

\section{French Railway Asphalt Trial Applications}

SNCF Engineering is performing field and laboratory tests to verify whether the asphalt sub-ballast could be considered as a suitable substitution material for utilise on high-speed railway constructions (Rail and Recherche, 2005). The comparison between the conventional track profiles constructed in the TGV-East network with the trial bituminous sub-ballast structure constructed in the $3 \mathrm{~km}$ trial line is shown in Figure 9.

\section{Spanish Railway Asphalt Trial Applications}

The Spanish Railways has constructed the alternative design in trial lines between Valladolid-Madrid, which is the high-speed passenger network and it has been operated, and between French border-Barcelona, which is the high-speed mixed traffic line, which is $70 \mathrm{~km}$ of the line already operated for freight trains in the end of 2010. These sections consist of the structural design with a $12 \mathrm{~cm}$ to $14 \mathrm{~cm}$ layer of 
asphalt sub-ballast lied over a form layer with $30 \mathrm{~cm}$ minimum thickness on top of a subgrade. As shown in Figure 10, this subgrade has a minimum bearing capacity of $80 \mathrm{MPa}$ (Teixeira, 2009).

\section{Austrian Railway Asphalt Applications}

Over a long period, asphalt track-beds technical experience and economic effect evaluation have developed by Austrian Federal Railways. Typically the thickness of a bituminous layer is between $8 \mathrm{~cm}$ to $12 \mathrm{~cm}$ and placed below the ballast-bed. The asphalt is installed using conventional rail unbound equipment and allows using it as a road for further construction and track placements. The superstructure is built later with state-of-art track laying equipment. The principal bituminous layer objective is to offer a clear separation between substructure and superstructure (Rose, Texeira and Veit, 2011). The main benefits are: prevent the rainwater from penetrating the substructure (sub-ballast and subgrade); prevent the fines pumping upward; obtain the elasticity at the optimum level; and provide the reliable support and homogenous stresses on the substructure.

According to the various studies, asphalt trackbed performs satisfactorily, and it can offer a rigid supportive layer that proper to substitute the crushed stone ballast layer. This design can behave slight plastic adaptability when it is required due to the asphalt characteristics. When greater stresses appear underneath particular sleepers than below others, due to its visco-elastic characteristics, asphalt will deform till a new equilibrium has been formed leaving the pressures more levelled. Other benefits of these designs are that allow sleepers replacement in case of damage by derailments and are easy to maintained (Esveld, 2001).

\section{Scrap Rubbers In Railway Track-Bed}

According to the research conducted by SolSánchez et al. (2015), the use of materials from cutting up scrap tires (Figure 11) as elastic materials (no-binder) between ballast materials would be a potential solution since the idea could reduce ballast degradation and it could increase an abundant waste material consumption. The application of crumb rubber also potentially lessen the ballast materials consumption since it could decrease ballast replacement frequency due to lower aggregates deterioration, and at the same time, the ballast mechanical performance and durability are modified due to the rubber elastic properties. The physical properties and the mechanical component of crumb rubber that has to be considered are granulometry, particle morphology, density $(\mathrm{mg} / \mathrm{m} 3)$, metal content $(<$ $0.1 \%)$, moisture content $(<0.75 \%)$, and textile substance $(<0.5 \%)$.

Results reveal that the $10 \%$ of crumb rubber utilisation (by volume) not only could diminish aggregates deterioration but also its stiffness is reduced since the ballast layer capability to dissipate energy is increased. Moreover, the settlement of track could be decreased due to $10 \%$ rubber particles used as flexible materials. However, an increase in rubber usage also generates the greater total of settlement and rate of settlement, which could be caused by the higher dynamic vertical movement. Thus, the crumb rubber utilisation with higher percentages such as $20 \%-30 \%$ (by volume) could be directed to higher long-term track geometry degradation (its stiffness is reduced, or extreme flexibility occurs) (Sol-Sánchez et al., 2014; Sol-Sánchez et al., 2015).

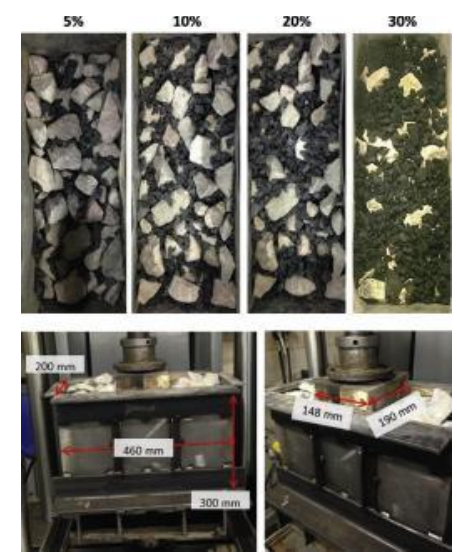

FIgURE 11. Ballast Box Configuration And Ballast Materials Mixed With Various Percentages of Rubber Particles (5, 10, 20 and 30) (Sol-Sánchez et al., 2015) 


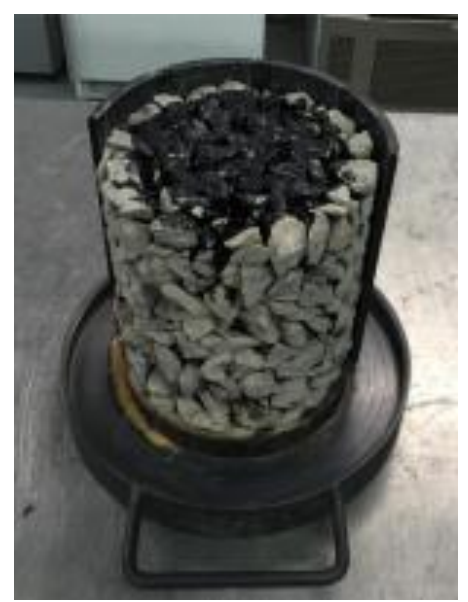

FIgURE 12. Visual Appearance of The Bitumen Stabilized Ballast After Emulsion Setting (D'Angelo et al., 2016)

Thus, further research should be conducted to achieve the knowledge of ballast behaviour with scrap tires rubber as elastic materials:

- Proving the crumb rubber effectiveness under various conditions and effects that usually occur in railway tracks such as water immersion, heat (high temperature), maintenance tasks impact, and windborne susceptibility.

- The durability of the material under a more significant number of loading cycles.

- Further research in real scale, related to its applicability and maintainability.

\section{Bitumen Emulsion In Railway Track-Bed}

D'Angelo et al. (2016) used bitumen emulsion in their research as a new alternative for ballast stabilisation technique which is poured from above into ballast layer so it can keep the excellent drainage properties (Figure 12). The analysis of the bitumen emulsion potential that poured at ambient temperature, as a stabilisation technique for ballast with clean and fouled condition is presented in this study. This method targets to decrease the settlement of track-bed and enhance its durability by modifying the mechanical behaviour of ballast (both stiffness and capability of energy dissipation of the layer).

The parameters of bitumen emulsion that has to be considered are:

- Dosage and Properties

Binder content $3 \%$ and $5 \%$ which is selected corresponding to standard bitumen stabilised materials used for cold mix asphalt on roads.

- Compaction Method
This parameter is conducted by applying the vibrator machine to simulate the conditions after construction/routine maintenance, when dynamic track stabiliser is used or not used.

Results showed that the bitumen emulsion utilisation as stabilisation method improve ballast resistance to permanent deformation significantly (higher when the dosage was increased) by enhancing stiffness and damping properties. This strengthening effect could be advantageous for decreasing rail stresses and deflection, and track-bed settlement. To achieve enhanced in-field performance, scenarios with a higher bitumen emulsion dosage and viscosity, quicker setting behaviour, and harder base bitumen, represent the most desirable conditions. The higher energy dissipation (viscoelastic) properties of this method (to dampen dynamic overloads) could suggest a valuable capability of this method to improve both short-term and long-term characteristics and sustainability of ballasted track. It also useful to mitigate ballast settlement problem (D'Angelo, et.al, 2016).

Thus, further research could be conducted to complete the bitumen stabilised ballast performance understanding:

- Proving the bitumen stabilised ballast performance effectiveness under various conditions and effects that usually occur in railway tracks such as water immersion, heat (high temperature), and maintenance tasks impact.

- The optimisation of bitumen emulsion properties type.

- Further research in real scale, related to its maintainability and applicability. 


\section{CONCLUSION}

Other solutions for the unconventional track design are the presence of asphalt layers within the railway substructure, and bitumen stabilised ballast utilisation to improve track performance, optimise the distribution of stress, dampen the dynamic overloads, and reduce vibrations which result in the capability of long-term performance improvement and ballasted track sustainability assurance. The benefits of crumb rubber (from cutting up end-of-life-tire) utilisations are to decrease life-cycle costs by increasing the durability of ballast layer itself and reducing ballast aggregates consumption (postponing and diminishing the need for extraordinary maintenance such as ballast cleaning or renewal). Due to the rubber particle resistance to deterioration, the scrap tires (waste materials) also could be reused and reclaimed which would be directed to the sequences of socio-environmental advantages. The railway track is an essential infrastructure in the railway systems so its quality and performance will determine the comfort and safety of train travel.

Researchers mainly use rubber (from scrap tires) only with ballast, or bitumen as ballast stabilisation only, or asphalt layer under ballast only. There are no researchers' uses these three methods together in their research. Each design has its benefits and limitations, so if these three methods are combined, then they will complete each other and will produce better output.

The author suggests developing a new track structural components design that combined asphalt layer, rubber, bitumen emulsion. This new design expected to have capabilities to serve both high-speed railway lines and existing railway track corridors more cost-effectively compare to the conventional tracks in consequence of their potential to have greater structural quality and stability, considerably lower maintenance works, and more servicelife. It can serve the train journey with higher speed (so people can reach the destination faster) and higher axle load (so the train can bring more people and more goods).

\section{REFERENCES}

Berawi, et al. (2010). Evaluating Track Geometrical Quality Through Different Methodologies.
International Journal of Technology, 1: 38-47, ISSN 2086-9614.

Bitume Info. (2005). Sous Les Rails, le Bitume. No. 10, October, 2005.

D'Angelo, G., Thom, N.H., Lo Presti, D. (2016). Bitumen Stabilised Ballast: A Potential Solution for Railway TrackBed, Journal of Construction and Building Materials, Vol. 124, page 118-126.

Darr, E and Fiebig, W. (2006). Feste Fahrbahn: Konstrktion und Bauarten für Eisenbahn und Strassenbahn, Second Edition. Eurailpress. Germany.

Esveld, C. (1997). Innovations in Railway Track. Conferntie Railtech. Delft University.

Esveld, C. (2001). Modern Railway Track, Second Edition. Delft University of Technology.

Esveld, C. and Markine, V. (2003). Slab Track Design for High-Speed. Delft University of Technology.

Franz, Q. (2001). Innovative Track Systems Technical Construction. Project funded by the European Community, Directorate General Energy and Transport Under the 'Competitive and Sustainable Growth' Programme. ProMain. TÜV Intertraffic, Cologne. Oct. 2001.

Huang, H., Tutumluer, E., Dombrow, W. (2014). Laboratory Characterization of Fouled Railroad Ballast Behavior. Transportation Research Record: Journal of the Transportation Research Board, Print ISSN: 03611981.

Lee, S. H., Lee, J. W., Park, D. W., Vo, H, V. (2014). Evaluation of Asphalt Concrete Mixtures for Railway Track, Journal of Construction and Building Materials, 73, 13-18.

Lichtberger, B. (2005). Track Compendium, First Edition. Eurail Press.

Lidén, T. (2015). Railway Infrastructure Maintenance - A Survey of Planning Problems and Conducted Research. 18th Euro Working Group on Transportation, EWGT 2015, 14-16 July 2015, Delft, The Netherlands. 
Liu, et al. (2015). Establishment of Track Quality Index Standard Recommendations for Beijing Metro. Hindawi Publishing Corporation, Discrete Dynamics in Nature and Society, Volume 2015, Article ID 473830, 9 pages.

Michas, G. (2012). Slab Track Systems for High-Speed Railways. Master Degree Project, Division of Highway and Railway Engineering, Royal Institute of Technology, Stockholm, Sweden.

Momoya, Y. (2007). New Railway Roadbed Design. Railway Technology Avalanche, December, pp. 118.

Momoya, Y. and Sekine, E. (2007). Performance-based Design Method for Railway Asphalt Roadbed. Doboku Gakkai Ronbunshuu E, Vol. 63, pp. 608-619.

Profillidis, V.A. (2006). Railway Management and Engineering. Ashgate Publishing Limited, USA.

Rail and Recherche. (2005). Asphalt Travels from Highway to Railway. No.34, Jan/Feb/Mar, 2005.

Rose, J, G., Texeira, P, F., Veit, P. (2011). International Design Practices, Applications, and Performances of Asphalt Bituminous Railway Trackbeds.

Rose, J. G. (2013). Selected In-Track Applications and Performance of HotMix Asphalt Track-beds, In: 2013 Joint Rail Conference, pp. V001T01A017-V001T01A017.

Rose, J. G. (2014). Hot-Mix Asphalt Railway (Bituminous) Railway Track-beds: InTrack Tests, Evaluations, and Performances - A Global Perspective.

Rose, J. G., Souleyrette, R. R. (2014). Hot-Mix Asphalt Railway (Bituminous) Railway Track-beds: In-Track Test, Evaluations, and Performances - A Global Perspective, "When Rail Meets Soil" Technical Workshop Caltrain Headquarters San Carlos, CA, May 14, 2014.

Rose, J. G., Teixeira, P. F., Ridgway, N. E. (2010). Utilisation of Asphalt/Bituminous Layers and
Coatings in Railway Track-beds - A Compendium of International Applications. Proceedings of The 2010 Joint Rail Conference. Urbana, Illinois, USA. April 2010.

Sadeghi, J and Askarinejad, H. (2012). Application of Neural Networks in Evaluation of Railway Track Quality Condition. IJE Transactions B: Applications, Vol. 20, No. 3, December 2012.

Setiawan, D. M. (2013). Conventional and Unconventional Railway Track for Railways on Soft Ground in Indonesia (Case Study: Rantau Prapat - Duri Railways Development). Proceeding of 16th International Symposium of Indonesian Inter University Transportation Studies Forum (FSTPT). Universitas Muhammadiyah Surakarta.

Setiawan, D. M. (2016). Pembatasan Kecepatan Maksimum dan Kaitannya Terhadap Kapasitas Lintas Jalur Kereta Api Muara Enim - Lahat Sumatera Selatan. Prosiding Seminar Nasional Teknik Sipil 2016 ISSN : 2459-9727, Fakultas Teknik Universitas Muhammadiyah Surakarta.

Setiawan, D. M., Rosyidi, S, A, P. (2016). Track Quality Index as Track Quality Assessment Indicator. Prosiding Simposium XIX FSTPT, Universitas Islam Indonesia, 11-13 Oktober 2016.

Sol-Sánchez, M., Moreno-Navarro, F., RubioGamez, M,C. (2014). The Use of Deconstructed Tires as Elastic Elements In Railway Tracks, Journal of Materials (Basel) 7, 5903-5919.

Sol-Sánchez, M., Thom, N. H., MorenoNavarro, F., Rubio-Gamez, M. C., Airey, G. D. (2015). A Study Into The Use of Crumb Rubber in Railway Ballast, Journal of Construction and Building Materials, 75, 19-24.

SSF Ingenieure AG. Ballast-less Track on High-Speed Lines. Germany. www.ssf-ing.de.

Teixeira, P. F. (2009). State of the Art on the Use of Bituminous Subballast on European High-Speed Rail Line. Workshop on Railroad Track Design 
Including Asphalt Track-bed, BCR2A conference - Eight International Conference on Bearing Capacity of Roads, Railways and Airfields. The University of Illinois at UrbanaCampaign (USA), June-July 2009.

Texeira, P. F. and Lopez-Pita. A. (2005). Viability of Using Bituminous Subballast Layer on High-Speed Ballasted Tracks. Proceeding of the BCRA2005 - International Conference on Bearing Capacity of Roads, Railways and Airfields Conference, Trondheim, Norway, 2729 June 2005.

Texeira, P. F., Lopez-Pita, A., Bachiller, C. A., Robusté, F. (2006). Improvements in High-Speed Ballasted Track Design: Benefits of Bituminous Subballast Layers. Transportation Research Record: Journal of the Transportation Research Board $\mathrm{N}^{\mathrm{o}}$ 1943, 2006, pp.43-49, ISSN 0361-1981, ISBN 0309-09425-9.

Texeira, P. F., Lopez-Pita, A., Ferreira, P. A. (2010). New Possibilities to Reduce Track Costs on High-Speed Lines Using a Bituminous Sub-Ballast Layer, International Journal of Pavement Engineering, 11: 4, 301 307.
Tutumluer, E. (2011). Field Validated Model for Predicting Railroad Ballast Behavior. Hay Railroad Seminar 2011, Rail Transportation Engineering Center, UIUC, United States.

Woodward, P. K., El Kacimi, A., Laghrouche, O., Medero, G., Banimahd, M. (2012). Application of Polyurethane Geocomposites to Help Maintain Track Geometry for High-Speed Ballasted Railways Tracks, Journal of Zhejiang University - SCIENCE A (Applied Physics \& Engineering), ISSN 1673-565X (Print); ISSN 18621775 (Online).

Yahya, Qi. (2012). Identifikasi Penyebab Kantung Balas Pada Jalan Rel Berdasarkan Karakteristik Balas dan Drainase. Skripsi. Fakultas Teknik, Universitas Indonesia.

PENULIS:

Dian M Setiawan

Program Studi Teknik Sipil, Fakultas Teknik, Universitas Muhammadiyah Yogyakarta, Kabupaten Bantul, D.I. Yogyakarta.

Email: diansetiawanm@ft.umy.ac.id 